\title{
OCCURRENCE OF SOME MAASTRICHTIAN DINOFLAGELLATE CYSTS FROM THE UPPER CRETACEOUS SEDIMENTS OF THE BIDA BASIN, NIGERIA: IMPLICATIONS FOR AGE AND PALEOENVIRONMENTS.
}

J. OJO, OLUSOLA

(Received 17 August 2009; Revision Accepted 18, June 2010)

\begin{abstract}
Lithostratigraphic and palynological studies of the shale facies of the upper Cretaceous Patti Formation, southeastern Bida Basin, Nigeria have allowed the determination of the paleoenvironment and age of the sediments. Marine dinocysts assemblage and terrestrial pollen and spores (relatively more abundant) are well preserved in the sections. The marine dinocysts include diverse species of the genera Dinogymnium, Senegalinium, Andalusiella and Spiniferites. This assemblage reflects influence of shallow marine process during sedimentation of the shales and they provide, for the first time, incontrovertible evidence of the presence of marine condition in southeastern part of the Bida Basin.

A Maastrichtian age is suggested for the Shale facies of the Patti Formation in the study area based on the occurrence of well known Maastrichtian marine dinoflagellates Dinogymnium acuminatum, Dinogymnium digitus, Senegalinium bicavatum, Senegalinium psilatum and Paleocystodinium australinium. Associated with these forms also are some Maastrichtian spores and pollen; Buttinia andreevi, Cristaeturites cristatus, and Retidiporites magdalenensis.

This study therefore, is considered significant as it also confirms marginal marine connection between the Anambra and Bida basins and consequently is a proof that the later formed a part of the links between the Tethys sea and the south Atlantic sea in the Maastrichtian time.
\end{abstract}

KEY WORDS: Bida Basin, Patti Formation, Maastrichtian

\section{INTRODUCTION}

The Bida Basin also known as middle Niger Basin or Nupe Basin lies within west central Nigeria and trends in the northwest southeast direction (Fig. 1). This hinterland Basin consists of Upper Cretaceous clastic sequence of sandstones, shales, siltstones and ironstones which are considered non petroliferous. Previous account of the geology indicates a rift related origin (King 1950; Kogbe et al., 1981; Ojo and Ajakaiye, 1989), associated with the Benue Trough system and drifting apart of African and Brazilian plates.

The Patti Formation which is the only stratigraphic unit containing carbonaceous shales in the Bida Basin is sandwiched between the older Campanian - I Maastrichtian Lokoja Formation (conglomerates, sandstones and claystones) and younger Agbaja Formation of mainly ironstone (Fig 2). Several studies particularly on sedimentology and lithostratigraphy of the sediments and their lateral equivalents in the northwest Bida basin have been undertaken and reported (Jones, 1958; Adeleye, 1973, 1974; Braide, 1992; Ladipo et al., 1994; Abimbola et al., 1999; Vrbkha et al., 1999). Recently, Ojo and Akande (2003) and Akande et al. (2005) provided detail information and interpretation of the sedimentological and organic geochemical characteristics of the sediments. Notably, published works dealing with biostratigraphy in the present study area are scarce. The few available ones are those of Jan Du Chene et al. (1978), Mebradu et al. (1986) and Agyingi (1993). The impression from these studies, which reported only non marine pollen/spores from the shales of the Patti Formation, is that the shales and siltstones are non - marine. The recent work of Ojo and Akande (2008) however indicated the presence of marine dinoflagellates in some intervals of the Patti Formation sections. The aims of this paper are therefore to i) describe the dinoflagellate assemblage recovered from the study area

ii) highlight the biostratigraphic significance of this assemblage and provide evidence of marine environment in the southeastern Bida Basin. This is important because it will help to correct the wrong but long held impression of zero marine condition in the study area. The new data is also expected to provide more understanding of the paleogeography of the Bida basin with respect to possible connection between the Tethys and the south Atlantic in the Late Cretaceous and also may also help resolve more resolutely the precise age of the Patti sediments.

J. Ojo, Olusola, Department of Geology, University of Ilorin, Ilorin, Nigeria. 


\section{LITHOLOGIES AND METHODS OF STUDY}

Due to lack of exploration wells or well preserved borehole samples in the study area, the samples, mainly shale facies were obtained from road and quarry exposures of the Patti Formation which are restricted to the centre of the Basin around Ahoko, along Lokoja - Abuja highway (Fig. 1). Two lithologic sections (quarry face and road cut) representing the shale claystone member of the Patti Formation (Ojo and Akande, 2006) were investigated on the basis of bed to bed measurements and systemic sampling of relevant intervals. The road cut section (about $26 \mathrm{~m}$ thick) consists of well bedded, alternating shales, siltstones, claystones and ironstones (Fig. 3). At the lower part of the section are beds of fissile, carbonaceous shale with average thickness of $0.5 \mathrm{~m}$ which exude sulfurous odour. The quarry section is about $20 \mathrm{~m}$ thick and the lithologies are similar to those in the road section (Fig. 4). Effort was made to reach the deeper part of the shales to avoid weathered samples. In both sections, 40 samples of the fresh carbonaceous shales and siltstones were selected and used in this study for palynological preparation. The palynological technique involved standard chemical extraction or maceration with application of $10 \% \mathrm{HCl}$ to remove the carbonates and $40 \% \mathrm{HF}$ for the silicate digestion. The heavy minerals were separated from the residue using heavy liquid ( $\mathrm{Na}$ - polywolfromat, 2.0 S.G). The separates were screened through 10um nylon sieve. Due to high carbon content of most of the samples, ultrasonic machine was used to clean the residues. Clean palynomorphs were subsequently mounted on glass slides using glycerine jelly. Microscopic study involving identification, counting and photographic documentation were done using Leitz Diaplan microscope.

\section{Dinoflagellate Assemblage}

The dinoflagellate cyst assemblage, which are restricted only to the lower part of the studied sections are relatively abundant but of low diversity. The microplanktons are mainly represented by the peridinoids which account for $50 \%$ (Fig 5). Others are spiniferates (33\%), microforaminiferal lining (13.5\%) and algae $(3.5 \%)$.

\section{Description of some figured dinoflagellates and spores/pollen \\ Senegalinium bicavatum (Plate 1 Fig. 2)}

Description: Shell is ovate shaped and non tabulate, intercalary archeopyle, tranverse furrow not distinct and longitudinal furrow present. One broad but short apical horn, 2 antapical horns of near equal lengths. Thin periphragm but endophragm is relatively thick.

Remarks: Its been reported in the Maastrichtian of Senegal N.W. Africa (Jain and Millepied, 1975) and northeastern Nigeria (Ojo and Akande, 2004).

Senegalinium psilatum (Plate 1 Fig. 4)

Description: Bicavate, shell is ovate, intercalary archeopyle below the apical horn, well developed tranverse furrow. Very short apical and antapical horns. Periphram is delicate and psilate.

Remarks: Well known and reported in Campanian Maastrichtian of Senegal (Jain and Millepied, 1975), Senonian to Maastrichtian, Gabon (Malloy, 1972) and
Maastrichtian Gombe Formation, northeastern Nigeria (Ojo and Akande, 2004).

Dinogymnium euclaensis (Plate 1 Fig. 6)

Description: Shell is biconical, cingulum prominent and divides shell into unequal halves, epicyst is longer than the hypocyst, apical end is blunt and more rounded than the antapical end. Archaeopyle is apical. Sulcus is broad and distinct.

Remarks: This species has been recorded in Maastrichtian S.E. Nigeria (Oloto, 1989), Maastrichtian Senegal (Jain and Millepied, 1975), Campanian to Maastrichtian sediments of Egypt (Schrank, 1984).

Dinogymnium accuminatum (Plate $1 \mathrm{Fig} .7$ )

Description: Shell is biconical and elongated. Cingulum is prominent, epitract is narrower than the broad hypotract and tranversed by thin longitudinal folds. Archaeopyle is apical. Surface is granular.

Remarks: Abundant in the Maastrichtian of Senegal Basin, W. Africa (Jain and Millepied, 1975), Maastrichtian, Carlifornia and Alabama (Evitt et al. 1967), Upper Cretaceous Brazil (Herngreen, 1975).

Dinogymnium digitus (Plate 1 Fig. 8)

Description: The shell is oblong, epitheca and hypotheca are almost equal. Archeopyle is apical. Tranverse furrow is distinct but not broad or deep. Longitudinal folds are relatively broad in the epitheca and hypotheca. Surface is granular.

Remarks: Previously known occurrence include Turonian, Kazakhastan (Vozzhennikova, 1967).

Paleocystodinium australinium (Plate 1 Fig. 9)

Description: Long and moderately broad, smooth apical and antapical horns, few longitudinal folds. Periphragm is close to endophragm.

Remarks: Previous known occurrence include; Maastrichtian of Senegal (Jain and Millepied, 1973), Maastrichtian - Paleocene of Gabon (Malloy, 1972) and Maastrichtian Nkporo Shale, southern Nigeria (Oloto, 1989).

Retidiporites magdalenensis (Plate 1 Fig. 18)

Description: Shape is cylindrical and having microfoveolate to reticulate sculptural elements.

Remarks: Previously known and reported from Maastrichtian Egypt, Upper Campanian - Maastrichtian Senegal (Schrank, 1987), in the Maastrichtian of southern Nigeria (Salami, 1990).

Cristaeturites cristatus (Plate 1 Fig. 16)

Description: Shape is oval and bilateral symmetry. Inaperturate and sculpture is echinate

Remarks: It has been recorded in the Maastrichtian W. Africa and Somalia (Schrank, 1994).

Buttinia andreevi (Plate 1 Fig. 17)

Description: Sphaeroidal pollen with smooth exine. It is periporate and tectate.

Remarks:widely reported from Maastrichtian West Africa e.a Gabon. Seneaal. Anaola Ivorv Coast. Toao. Niaer OCCURRENCE OF SOME MAASTRICHTIAN DINOFLAGELLATE C

\section{BIOSTRATIGRAPHIC IMPLICATIONS}

The present study reveals biostratigraphic significant dinocysts. The main constituents of this assemblage are Dinogymnium euclaensis, Dinogymnium acuminatum, Dinogymnium digitus, 
Senegalinium bicavatum, Senegalinium psilatum and Paleocystodinium australinium. This assemblage obviously compares closely with well known Upper Cretaceous assemblages in different part of the world and most strikingly Campanian - Maastrichtian sediments of West Africa. The good representation of the genus Dinogymnium in this section suggests a Maastrichtian age. Jain et al. (1975) and Evitt (1967) reported $D$. accuminatum and other Dinogymnium species from Jadukata and Mahadek Formations, India and dated it Maastrichtian. D. spp such as $D$. accuminatum and $D$. Euclaensis have been consistently reported as having marked representation in the Campanian to Maastrichtian sediments (Schrank, 1984, 1987; Sultan, 1985), Senegal Basin (Jain and Millepied, 1973), Maastrichtian of Carlifornia USA (Evitt, 1967), Upper Cretaceous Brazil (Herngreen, 1975). A number of other Campanian - Maastrichtian forms also occur in the samples. Notably, Senegalinium bicavatum, Senegalinium psilatum which have been reported from the Maastrichtian of Senegal, N. W. Africa (Jain and Millepied, 1975) are prominent in the study area. The above comparison suggests a Maastrichtian age for the sediments. The co - occurrence of $D$. euclaensis, $S$. bicavatum and $P$. australinium provide unimpeachable evidence for age neither younger nor older than Maastrichtian. Moreover, the Maastrichtian age appears most reasonable because the well known Tertiary elements (both dinocyst and spores/pollen) are absent. Comparison of this assemblage with those reported from Maastrichtian Nkporo Shale, Anambra Basin (Oloto, 1989), Gombe Formation, Gongola Basin (Ojo and Akande, 2004) shows striking similarities and positive correlation. It should be noted that the associated pollen and spores (Buttinia andreevi, Retidiporites magdalenensis) from same interval also indicate Maastrichtian age (Ojo and Akande, 2008).

\section{Paleoenviromental Synthesis}

The environments of deposition of the sediments of Patti Formation have been subject of discussion in various publications (Braide, 1992; Agyingi, 1991). The authors suggested non marine environments for the argillaceous rocks (shale - clayey member) of the Patti Formation. Recent investigation by Ojo and Akande (2006) and Akande et al. (2005) however recognized and reported certain marine sedimentological features such as herringbone and hummocky cross beddings and ophiomorpha burrows in these sediments. The occurrence of well preserved marine dinoflagellate cysts from the shaly intervals of the Patti Formation in the study area, being reported here for the first time, is therefore significant in the elucidation of the processes of sedimentation.

Palynological data have been found useful as paleoenvironmental synthesis tool (Van Bergen et al. 1990; Oloto, 1989; Petters and Edet, 1996; Vadja Santinavez, 1998; Ojo, 1999). In these studies, the interpretation is based on the ratio of land derived miospores to marine dinoflagellate and also the morphology of the dinocysts. Schrank (1984) suggested that a palynomorph assemblage with higher content of land derived miospores indicates terrestrial influence and vice versa. In this study, the occurrence of known marine dinoflagellates such as Dinogymnium, Senegalinium, Spiniferites and microforaminifera lining indicate marine flooding at the lower part of the sections. It is evident, however, from the low diversity of dinocysts with an abundant peridinoids than the chorate cysts that the salinity of the water was low. Harland (1978) posited that the ratio of gonyaulaceans to peridinoids provides an indication of salinity; the higher the ratio, the more open marine condition and vice versa. Here the ratio is extremely low, therefore indicating near shore or brackish water, probably less than 50m (Figs 6\&7). The predominance of the peridinoids clearly indicates estuarine environment (Downie et al. 1971), commonly inundated and diluted by run - off water. The unique feature of the Dinogymnium which is well represented in the assemblage from the studied section, is known to be specially adapted to extreme fluctuation in shallow marine settings (May, 1977).

An examination of the chitinous foraminiferal test linings which are common in the samples show that they are single chambered and uniserial. This shows an affinity to benthonic foraminiferal and therefore an indication of low salinity, brackish water environments. It is notable that the present dinocyst assemblage shows similarities with some of the Campanian - Maastrichtian dinocysts that are typical of the Tethyan regions. Many of the species are similar to those described from the Upper Cretaceous of southeast and southwest Nigeria (Salami, 1983, 1984). It can be deduced therefore that the Bida Basin provided a link between the Tethyan sea and the Gulf of Guinea in the Maastrichtian times.

The population and diversity of the dinocyst reduced upsection. In deed from the middle to top of section, no marine dinocyst is present. This may be an indication, that the lower part represents regression at the end of Maastrichtian. 


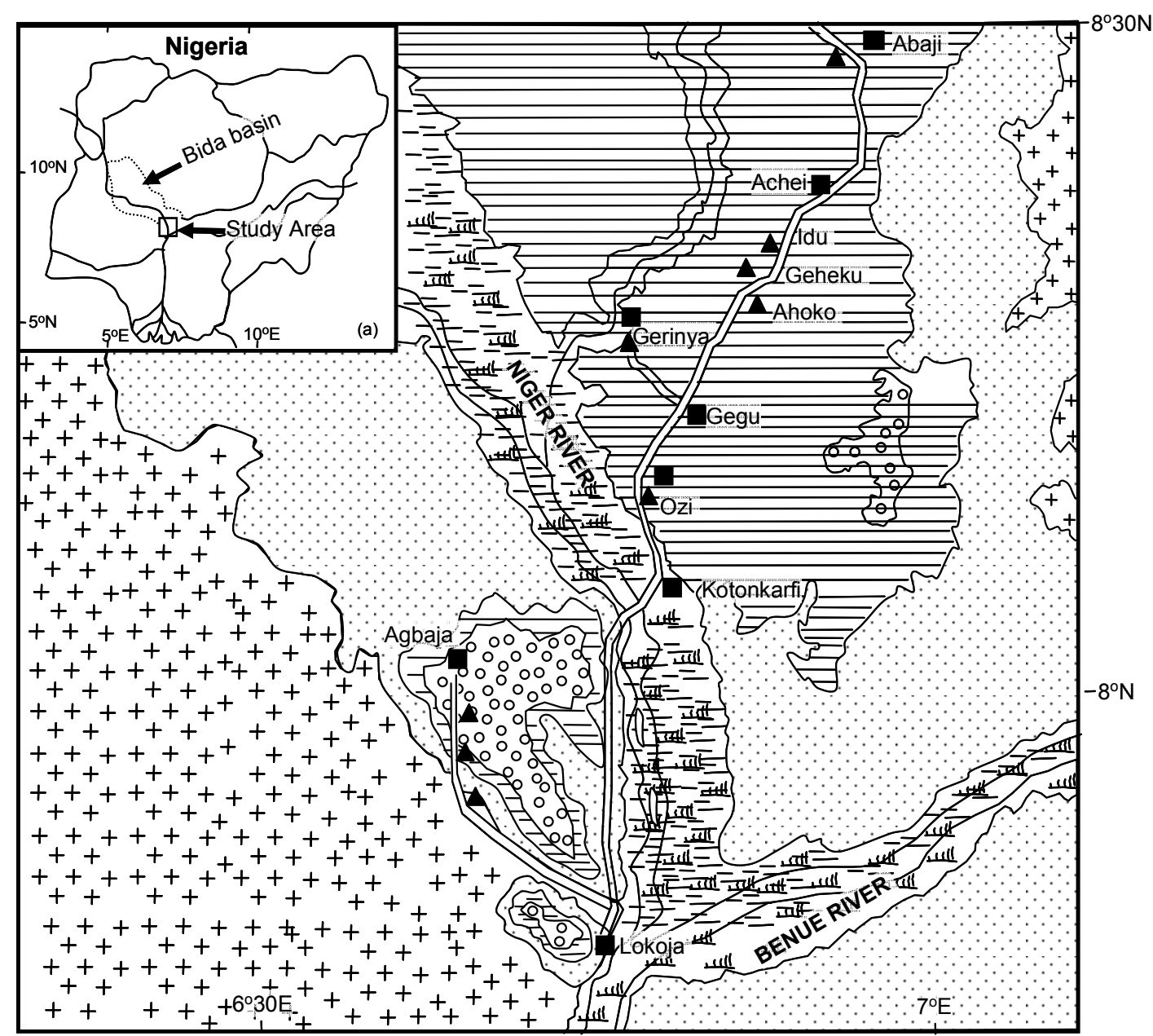

\begin{tabular}{rrr}
$0 \quad 5 \quad 10 K m$ \\
\hline
\end{tabular}

\section{LEGEND}

\begin{tabular}{|c|c|}
\hline$\frac{\text { IIII }}{4 \pi}$ & Alluvium Recent and Swamp Forest \\
\hline \begin{tabular}{|lll} 
& 0 & 0 \\
0 & 0 \\
\end{tabular} & Maastrichtian Agbaja Ironstone Formation \\
\hline & Maastrichtian Patti Formation \\
\hline & Campanian - Maastrichtian Lokoja Formation \\
\hline+ & Pre-Cambrian - Lower Palaeozoic Basement Complex \\
\hline
\end{tabular}

- Studied Outcrop Locations

Fig. 1 


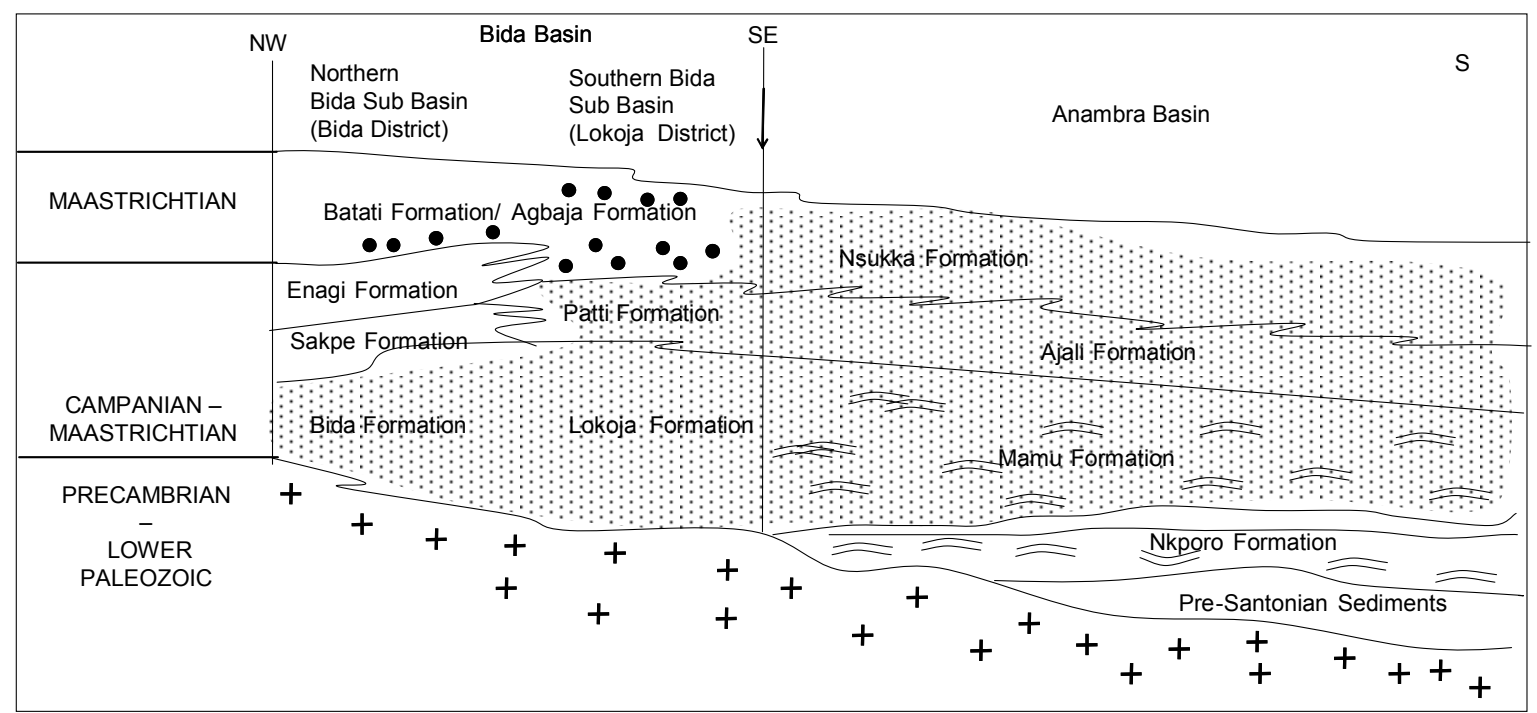

Fig. 2 


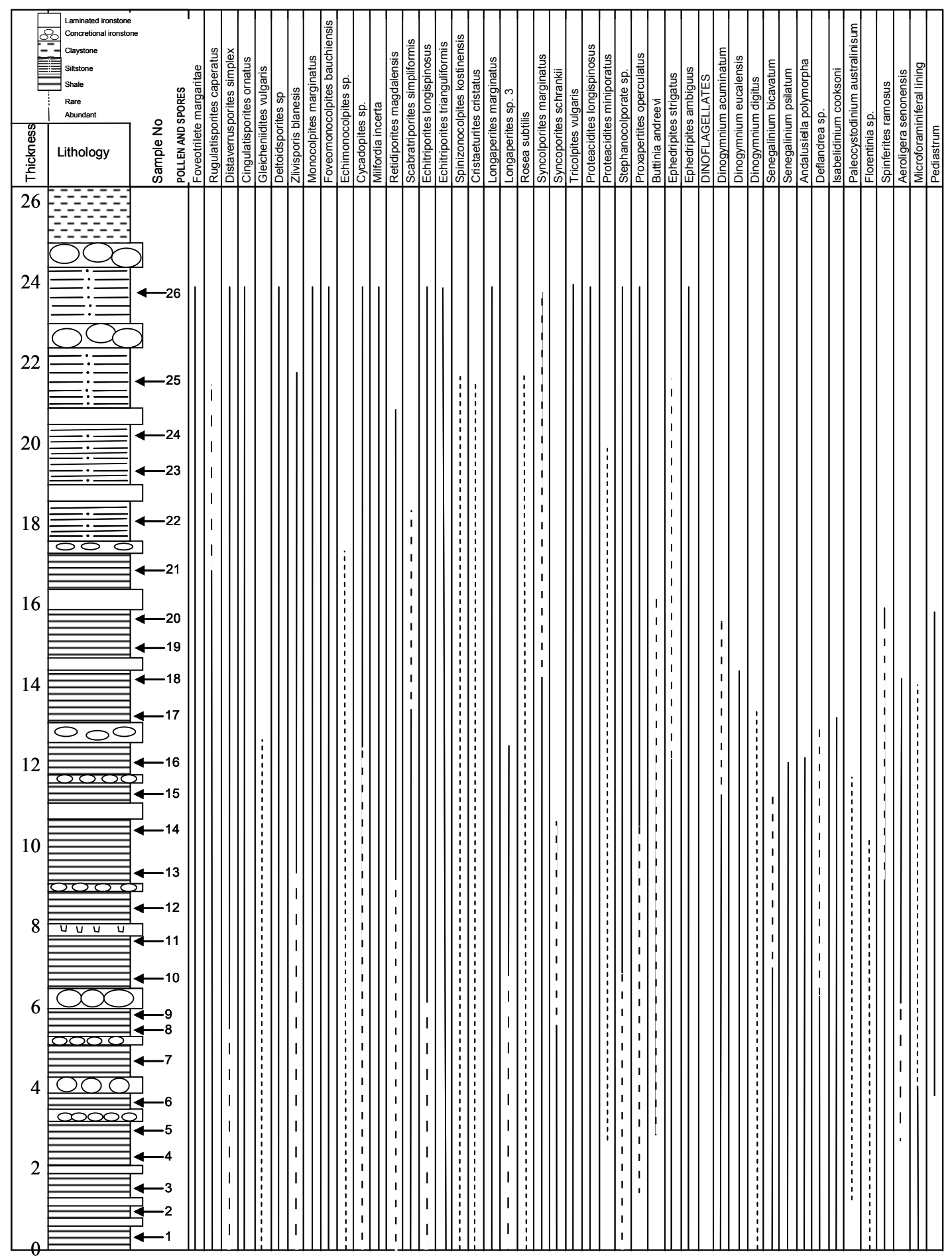

Fig. 3 


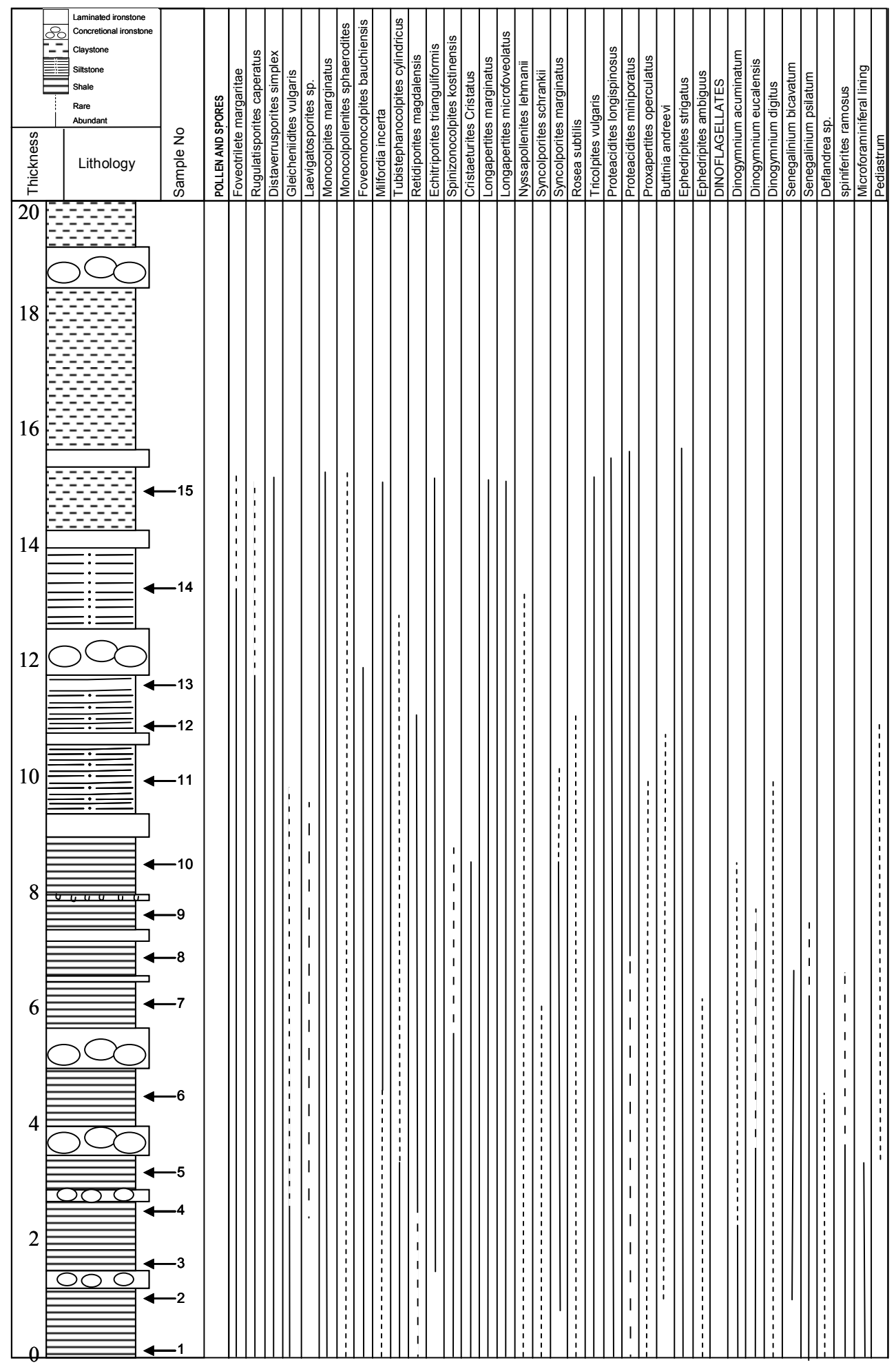

Fig. 4 


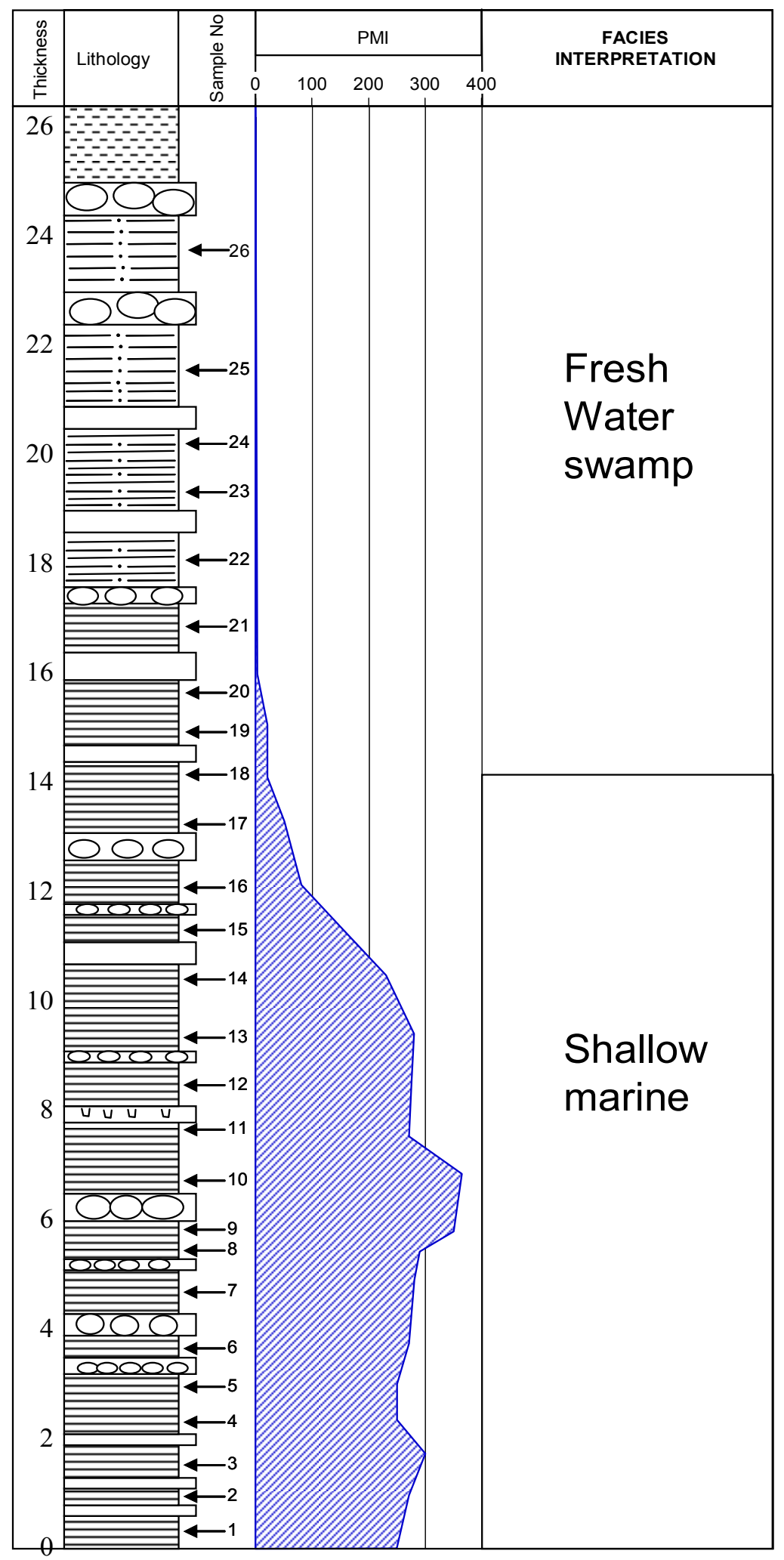

Fig. 5 


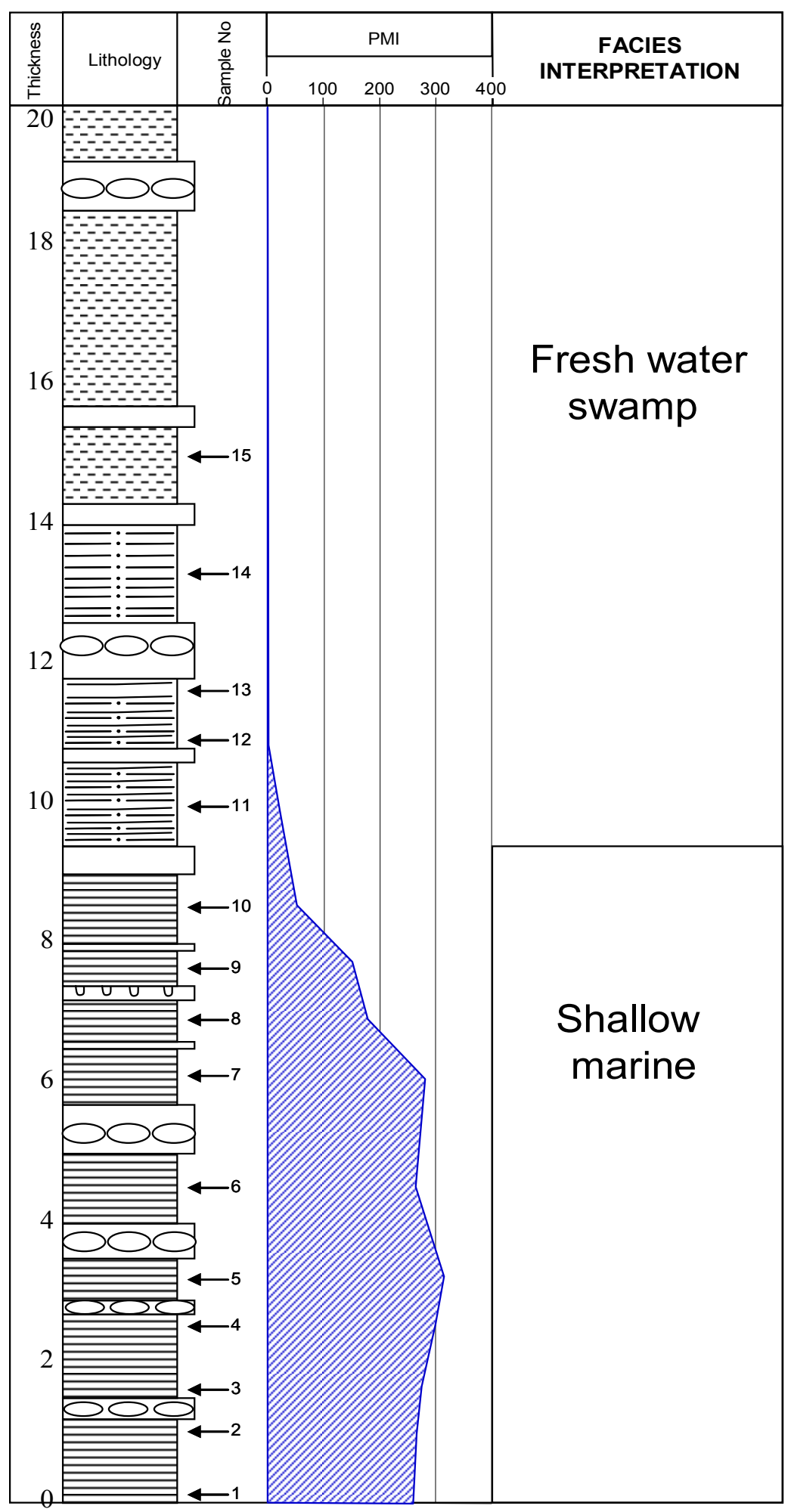

Fig. 6 


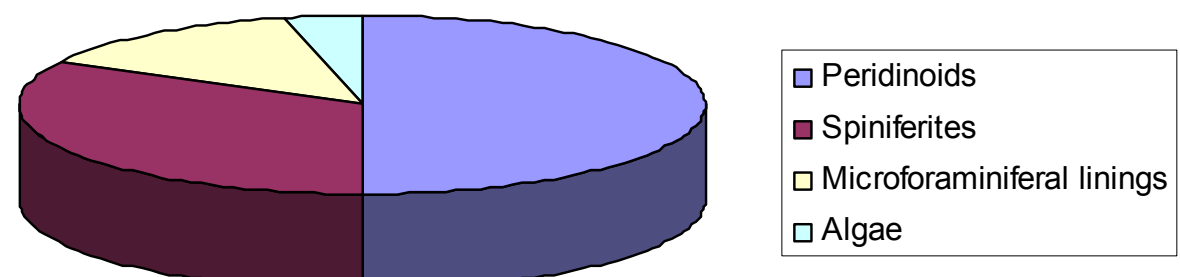

a

Frequency chart for the marine microplanktons group

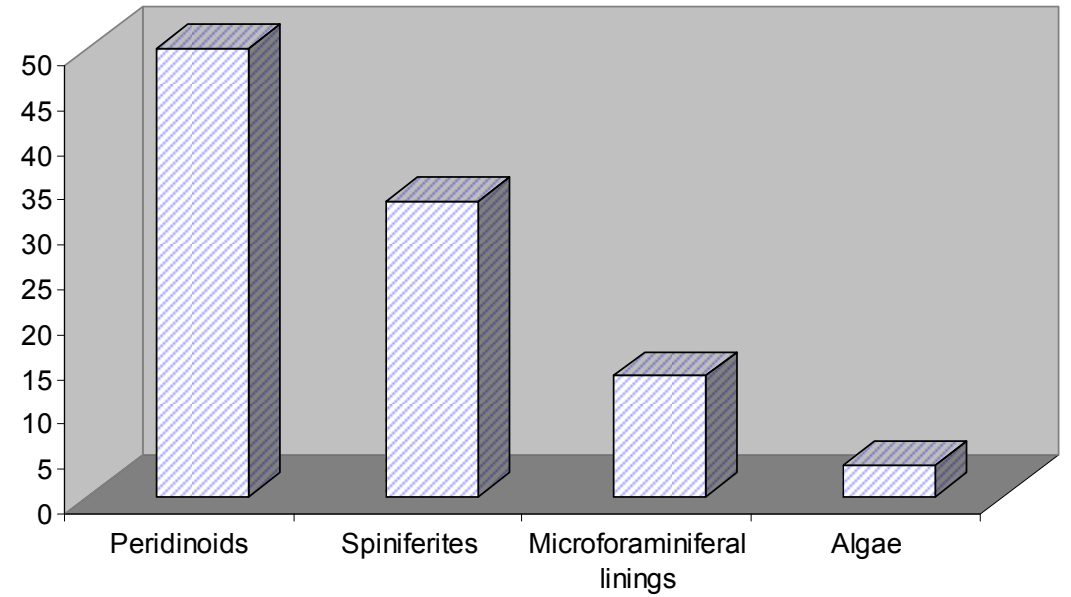

b

Fig. 7 


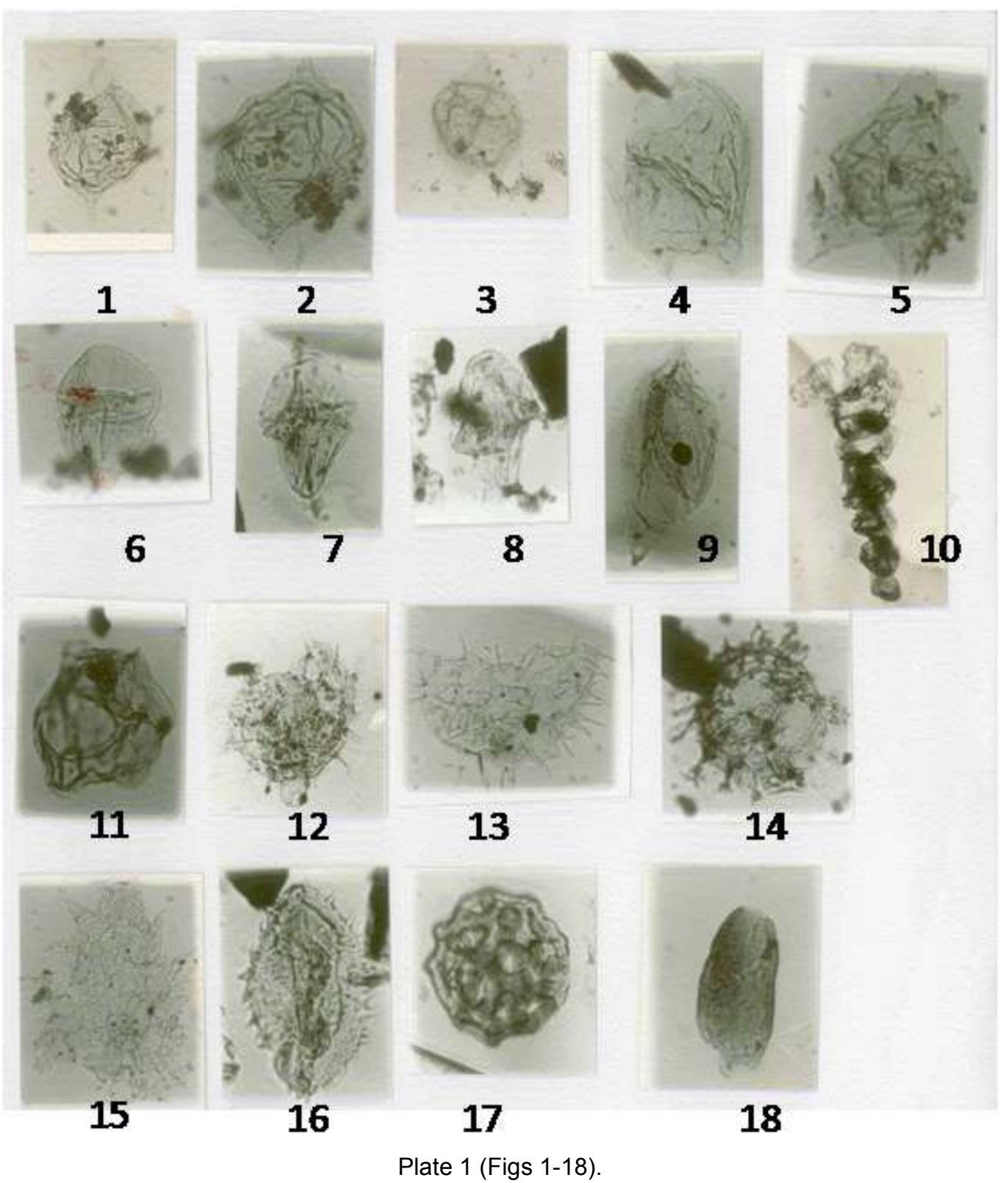

\section{CONCLUSIONS}

The palynomorph assemblage from the sections studied indicates predominance of terrestrial derived pollen and spores and significant representation of diverse marine dinoflagellates in the lower part of the section. The present data provide the first microplankton evidence of shallow marine condition in parts of the Patti Formation.

The sections of the Patti Formation is assigned Maastrichtian age and they correlate with part of Nkporo Shale in Anambra Basin and Gombe Formation in Gongola Basin, northeast Nigeria.

\section{AKNOWLEDGEMENTS}

Series of field mapping were undertaken during which the samples were collected. The company and stimulating suggestions of Prof. S. O. Akande,

Department of Geology, University of Ilorin, Nigeria is highly appreciated. The laboratory processing of the samples was carried out at the Institute of Geology and Paleontology, Technical University, Berlin during the tenure of post Doctoral award to the author by the German Academic Exchange, Germany (DAAD). Technical support of Ola Sayomi for drafting the figures is appreciated.

\section{REFERENCES}

Abimbola, A.F., Badejoko, T.A; Elueze, A.A., and Akande, S.O., 1999. The Agbaja Ironstone Formation, Nupe Basin, Nigeria. A product of replacement of a Kaolinite precursor. Global Journal of Pure and Applied Sciences 5: 375-384

\section{8}

Adeleye, D.R., 1973. Origin of ironstones, an example from the Middle Niger valley, Nigeria. Journal of Sedimentary Petrology 43: 709-727.

Adeleye, D.R., 1974. Sedimentology of the fluvial Bida Sandstones (Cretaceous) Nigeria. Sedimentary Geology 12: 1-24. 
Agyingi, C.M., 1991. Geology of upper Cretaceous rocks in the eastern Bida Basin, Central Nigeria. Unpublished Ph.D Thesis, University of Ibadan, Nigeria, 501pp.

Agyingi, C.M., 1993. Palynological evidence for a late Cretaceous age for Patti Formation, Eastern Bida Basin, Nigeria. Journal of African Earth Sciences 17: 513-523.

Akande, S.O., Ojo, O.J. and Ladipo, K; 2005. Upper Cretaceous sequences in the southern Bida Basin, Nigeria. A Field guidebook. Mosuro publishers, Ibadan, 60pp.

Braide, S.P., 1992. Geological development, origin and energy mineral resources potential of the Lokoja Formation in the southern Bida Basin. Journal of Mining and Geology 28: 33-44.

Downie, C., Hussain, M.A. and Williams, G. L., 1971. Dinoflagellate cysts and achritarch associations in the Paleogene of southeast England. Geoscience Man. 3: 29-35

Evitt, W. R., 1967, Dinoflagellate studies II Archeopyle. Stanford University Publs. Geol. Sci. vol 10(3): 1-83.

Harland, R., 1978. Dinoflagellate cysts and achritarchs from the Bearpaw Formation (Upper Campanian) of southern Alberta, Canada. Paleontology 16: 665-706.

Herngreen, G. F. W., 1975. An upper Senonian pollen assemblage of borehole 3-Pia-IO-AI, state of Alagoas, Brazil. Pollen et spores 17: 93-140.

Jain, K. P., Sah, S. C. D. and Singh, R. Y., 1975. Fossil dinoflagellates across Maastrichtian - Danian boundary in Lower Assam, Indian. Paleobotanists 22: 1-18.

Jain, K. P. and Millepied, P., 1973. Cretaceous microplankton from Senegal Basin, N.W. Africa I. Some new genera, species and combinations of dinoflagellates. Paleobotanists 20: 22-32.

Jan du Chene, R.E., Adegoke, O.S., Adediran, S.A., and Petters, S.W., 1978. Palynology and foraminifera of the Lokoja Sandstone (Maastrichtian), Bida Basin, Nigeria. Revista Espanola de Micropaleontotologia 10: 379 393.

Jones, H.A, 1958. The oolitic ironstone of Agbaja Plateau, Kabba Province. Record of the Geological survey of Nigeria, pp. $20-43$.

King, L.C., 1950. Outline and distribution of Gondwanaland. Geological Magazine 87: 353359.

Kogbe, C.A., Ajakaiye, D.E. and Matheis, G., 1981. Confirmation of rift structure along the Middle -
Niger Valley. Nigeria. Journal of African Earth Sciences 1: 127-131.

Ladipo, K.O., Akande, S.O. and Mucke, A., 1994. Genesis of ironstones from middle Niger sedimentary basin, evidence from sedimentological, ore microscope and geochemical studies. Journal of Mining and Geology 30: 161-168

Malloy, R. E., 1972. An upper Cretaceous dinoflagellate cyst lineage from Gabon, West Africa Geoscience and Man 4: 57-65.

May, F. E., 1977. Functional morphology, paleoecology and systematics of Dinogymnium tests. Palynology 1: 103-201

Mebradu, S., Imhanobe, J. and Kpandei, L. Z., 1986. Palynostratigraphy of the Ahoko sediments from the Nupe Basin, N.W. Nigeria. Review of Paleobotany and Palynology 48: 303-310.

Ojo, O. J. 1999, Depositional environments, palynological and organic geochemical studies of Gongola and Yola Basins, Nigeria: Implications for hydrocarbon potential. Ph.D. Thesis, University of Ilorin, 355pp.

Ojo, O. J. and Akande, S. O., 2003. Facies relationships and depositional environments of the Upper Cretaceous Lokoja Formation in the Bida Basin, Nigeria. Journal of Mining and Geology 39: 3948.

Ojo, O. J. and Akande, S. O. 2004, Palynological and paleoenvironmental studies of the Gombe Formation, Gongola Basin, Nigeria. Journal of Mining and Geology 40: 143-149.

Ojo, O. J. and Akande, S.O., 2006. Sedimentological and palynological studies of the Patti Formation, southern Bida basin, Nigeria: implications for paleoenvironments and paleogeography: Nigeria Association of Petroleum Explorationists Bulletin 19: 61-77.

Ojo, O. J. and Akande, S. O., 2008. Microfloral assemblage, age and paleoenvironment of the Upper Cretaceous Patti Formation, cnuthosctorn Rids Rocin Nlinoris. Inurnal of

\section{OCCURRENCE OF SOME MAASTRICHTIAN DINOFLAGELLATE C}

Ojo, S. B. and Ajakaiye, D. E., 1989. Preliminary interpretation of gravity measurements in the Middle Niger Basin area, Nigeria. In C.A. Kogbe (editor) Geology of Nigeria, $2^{\text {nd }}$ ed., Elizabethan Publishing Company, Lagos, pp.347-358.

Oloto, I. N., 1989. Maastrichtian dinoflagellate cyst assemblage from the Npkoro shale on the Benin Flank of the Niger Delta. Review of Paleobotany and Palynology 57: 173-186.

Petters, S. W. and Edet, J. J., 1996. Shallow shelf and anoxic facies in the Late Campanian - Early 
Maastrichtian of S.E. Nigeria. Geologie de l'Afrique et de l'Atlantique Sud: Actes Colloques Angers 1994, pp. 219-233.

Salami, M. B., 1983. Some late Cretaceous and Early Tertiary pteridophytic spores from the southern sedimentary basin. Rev. Esp. Micropaleont. 15: 257-272

Salami, M. B., 1984, Three new sporomorph genera from the late Cretaceous and Paleogene of southwestern Nigeria. Grana, 23, p.162-166.

Salami, M. B., 1990. Palynomorph taxa from the "Lower Coal Measures" deposits (? Campanian Maastrichtian) of Anambra Trough, southeastern Nigeria. Journal of African Earth Sciences11: 135-150.

Schrank, E., 1984. Organic geochemical and palynological studies of Dahkla Shale profile (Late Cretaceous) in southeast Egypt. Part A: succession of microfloras and depositional environments. Berliner geowiss, Abh., Reihe A, 50 , p.189-207

Schrank, E. 1987. Paleozoic and Mesozoic palynomorphs from northeast Africa (Egypt and Sudan) with special reference to Late Crtaceous pollen and dinoflagellates. Berliner geowiisenchaften, Abh., Reihe A, 75: 249-310

Schrank, E., 1994. Palynology of the Yeseomma Formation in northen Somalia: A study of pollen, spores and associated phytoplankton from the Late Cretaceous Palmae Province. Palaentographica Abt. B, 231: 63-112.

Schrank, E. and Ibrahim, M.I.A., 1995. Cretaceous (Aptian - Maastrichtian) palynology of foraminifera dated wells (KRM-1, Ag. 18) in northwest, Egypt: Berliner geowiss. Abh, A177: $1-44$

Vadja-Santinavez, V., 1998. Cretaceous palynofloras from southern Scandinavia: Lund Publications in Geology 35: 1-24

Van Bergen, P.F., Janssen, N.M.M., Alferink, M., and Kerp, J.H.F., 1990. Recognition of organic matter types in standard palynological slides. In. W.J.J. Fermont and J.W. Weegink (eds.), International symposium on organic petrology: Mededelingenrijks geologische dienst, 45, pp. 10-12.

Vozzhennikova, T. F. 1965. Voedenye $v$ izuchenye is kopayemyx Peridineyevyx Vodoroslei. Dokl. Akad. Nauk. SSSR, Moskova, Leningrad (Izdatelstvo "Nauka" Moskova): 1-156.

Vrbka, P., Ojo, O.J., and Gebhardt, H., 1999. Hydraulic characteristics of the Maastrichtian sedimentary rocks of the southeastern Bida Basin, Central Nigeria. Journal of African Earth Sciences 29: 659-667.

\section{LIST OF FIGURES AND PLATE}

Fig. 1 (a) Map of Nigeria showing NW/SE trending Bida Basin (b) Geological map of study area after Agyingi (1991) showing locations of studied sections.

Fig. 2 Regional stratigraphic successions in the Bida Basin and restored NW-SE-S stratigraphic relationships from the Bida basin to the Anambra Basin (Modified after Akande et al. 2005)

Fig. 3 Lithologic section and distribution of pollen and spore and dinoflagelates in the Patti Formation exposed at Ahoko, along Lokoja - Abuja highway.

Fig. 4 Lithologic sections and distribution of pollen and spores and dinoflagellates in the Patti formation exposed at Ahoko quarry.

Fig. 5 Palynological Marine Index (PMI) plot and facies interpretation of Patti Formation samples at Ahoko, along Lokoja - Abuja highway.

Fig. 6 Palynological Marine Index (PMI) plot and facies interpretation of Patti Formation exposed at Ahoko quarry.

Fig. 7 Frequency chart of the dinoflagellate groups in the study area (a) Pie chart (b) Bar chart. Plate 1

Fig. 1 Andalusiella polymorpha

Fig. 2 Senegalinium bicavatum

Fig. 3 Senegalinium bicavatum

Fig. 4 Senegalinium psilatum

Fig. 5 Deflandrea sp.

Fig. 6 Dinogymnium euclaensis

Fig. 7 Dinogymnium acuminatum

Fig. 8 Dinogymnium digitus

Fig. 9 Paleocystodinium australinium

Fig. 10 Microforaminifera lining

Fia. 11 Isabelidium cooksoni

\section{0}

Fig. 14 Spiniferites ramosus

Fig. 15 Pediastrum

Fig. 16 Cristaeturites cristatus

Fig. 17 Buttinia andreevi

Fig. 18 Retidiporites magdalenensis

Magnifications; Figs 1,3,4,5,9,10,16 x 800, others $x$ 1000. 